\title{
THE INFLUENCE OF UTILITARIAN VALUE, HEDONIC VALUE, SOCIAL VALUE, AND PERCEIVED RISK ON CUSTOMER SATISFACTION: SURVEY OF E-COMMERCE CUSTOMERS IN INDONESIA
}

\author{
Tri Yulistyawati EVELINA (1) ${ }^{*}$, Andriani KUSUMAWATI (1)2, \\ Umar NIMRAN ${ }^{1}{ }^{3}$, SUNARTID 4 \\ ${ }^{1}$ Business Administration Department, Politeknik Negeri Malang, Indonesia \\ 1, 2, 3, 4 Faculty of Administrative Science, Universitas Brawijaya, Malang, Indonesia
}

Received 20 February 2020; accepted 27 May 2020

\begin{abstract}
The purpose of this study is to build an understanding of the influence of utilitarian value, hedonic value, social value, and perceived risk on e-commerce customer satisfaction in Indonesia. Data was collected through an online survey and analyzed using Structural Equation Modeling (SEM) with the WarpPLS tool version 6.0 which was then analyzed through Inferential Statistics analysis. The results of the study showed that utilitarian value significantly influences customer satisfaction. Hedonic value significantly influences customer satisfaction. However, the findings showed that social value did not have a significant effect on customer satisfaction, meaning that the level of the social value of e-commerce customers does not have a significant impact on the level of customer satisfaction. Finally, the results show, perceived risk significantly influences customer satisfaction.
\end{abstract}

Keywords: utilitarian value, hedonic value, social value, perceived risk, customer satisfaction, e-commerce.

JEL Classification: M310.

\section{Introduction}

Consumers as users of products and services offered in e-commerce, opinions, or inclusion cannot be ignored because it can help e-commerce marketers to formulate an appropriate marketing strategy. The existence of consumers influences achieving the company's final goal, namely the acquisition of high profits from the purchase of products and services. This requires companies to know what factors can influence customers in making product purchase decisions. Customers as users will contribute to the process of selling, comparing, and sharing various products and services both online and offline (Chunmei \& Weijun, 2017). Customers not only learn how to evaluate products and services but also ask for advice from others before buying, share experiences about products and services after buying. The subjective evaluations of customers produced when comparing the experience of using goods and services with previous expectations reflect customer satisfaction (Constantin, 2013). Satisfaction has been identified as an important factor influencing purchase intentions (Constantin, 2013; Molinillo et al., 2017). Therefore, e-commerce marketers need to pay attention to the motives that encourage customers involved in ecommerce activities especially focusing on perceived value in consumer behavior as customers. Utilitarian Value becomes an important factor in assessing customer behavior in e-commerce offline (Chunmei \& Weijun, 2017; Avcilar \& Özsoy, 2015). Consumers who will make purchasing decisions by considering its Utilitarian Value will be more objective in assessing a product (Kesari \& Altukar, 2016). The higher value of the benefits received by customers from e-commerce, the more satisfied customers will feel. Besides, Hedonic Value is also an important factor in assessing customer behavior in e-commerce.

Hedonic Value as a value received by customers based on pleasant experiences and pleasures. Hedonic Value is more subjective and personal than Utilitarian Value and is more about fun than from the composition of tasks. The results showed that Hedonic Value had a significant effect on e-commerce customer satisfaction (Avcilar \& Özsoy, 2015; Hanzaee \& Rezaeyeh, 2013). The higher the value

${ }^{*}$ Corresponding author. E-mail: trievelina@polinema.ac.id 
received by customers based on the pleasant experience and pleasure of e-commerce, the more satisfied customers would feel (Chunmei \& Weijun, 2017).

According to Rintamäki et al. (2006), social value plays an important role in determining customer behavior. The effect of social value on customer satisfaction has been investigated in the context of social commerce in China (Chunmei \& Weijun, 2017). Social value is the benefit of a product or service aimed at satisfying one's desires in gaining recognition or social pride (Sheth \& Mittal, 2004). Some studies have confirmed that Social Value has a significant effect on customer satisfaction (Chunmei \& Weijun, 2017; Hu et al., 2014; Kang \& Kim, 2017). This study indicates that the more users can feel the social value the more satisfaction it receives (Chunmei \& Weijun, 2017).

Furthermore, the Perceived Risk factor as a condition of uncertainty regarding the negative consequences that may arise from using goods and services (Bauer, 1960), is indicated to affect customer satisfaction (Cheng \& Lee, 2011; Martin et al., 2015). The lower the Perceived Risk the customer will further increase customer satisfaction (Chunmei \& Weijun, 2017). Satisfaction is defined as the user's evaluation of online sales based on their needs and expectations which refers to the positive emotional condition of the user that comes from using the service (Chunmei \& Weijun, 2017). Satisfaction reflects the subjective evaluations of users generated when comparing usage experience with previous expectations about an e-commerce site.

Previous research has empirically examined the effect of perceived value on e-commerce user behavior (Chunmei \& Weijun, 2017). However, previous studies are still very general, especially focusing on perceived value and less attention to social values and perceived risks in purchasing using e-commerce. Consumers in shopping not only look for utilitarian and hedonic values such as comfort and pleasure but also pay attention to social values such as interacting with others and self-fulfillment (Rintamäki et al., 2006). Shopping for e-commerce also provides conditions of uncertainty about the negative consequences that may arise from using goods and services (Bauer, 1960). This is also a consideration for consumers to get the satisfaction of shopping e-commerce. Thus, this study parses perceived value in three dimensions namely utilitarian value, hedonic value, and social value (Rintamäki et al., 2006), and also explores perceived risk as uncertainty conditions that influence consumer satisfaction in shopping using e-commerce.

This study aims to answer the following questions: (1) To what extent is perceived value and perceived risk can affect consumer satisfaction in shopping using ecommerce? (2) How the implications of this research are used by e-commerce vendors in developing appropriate marketing strategies.

To achieve the research objectives, this study aims to test the purchase intentions of e-commerce consumers by proposing and empirically testing a theoretical model. Empirical data was collected through surveys of e-commerce customers in Indonesia. Then the structural equation model is carried out to assess the model and test the hypothesis. This study examines the behavior of consumers who shop using e-commerce technology with perceived value so that this research can enrich related studies and provide a more complete understanding of consumer behavior using e-commerce. Also, this research will provide advice for e-commerce vendors on how to approach e-commerce users and maintain it.

\section{Literature review}

Perceived value is "the consumer's overall assessment of the utility of a product based on perceptions of what is received and what is given" (Zeithaml, 1988), which reflects the trade-off between perceived benefit and perceived risk (Chunmei \& Weijun, 2017). Perceived benefit is related to the benefits users obtain from the products or services, while perceived risk refers to the costs incurred to obtain the products or services (Chunmei \& Weijun, 2017; Zeithaml, 1988; Wood \& Scheer, 1996). Literature studies have shown that hedonic and social dimensions of customer value are seen as meaningful and important aspects that complement the traditional utilitarian perspective (Rintamäki et al., 2006).

Utilitarian Value becomes an important factor in assessing customer behavior in e-commerce offline (Chunmei \& Weijun, 2017; Avcilar \& Özsoy, 2015). Consumers who will make purchasing decisions by considering its Utilitarian Value will be more objective in assessing a product (Kesari \& Altukar, 2016). The higher value of the benefits received by customers from e-commerce, the more satisfied customers will feel. Besides, Hedonic Value is also an important factor in assessing customer behavior in e-commerce.

Hedonic Value as a value received by customers based on pleasant experiences and pleasures. Hedonic Value is more subjective and personal than Utilitarian Value and is more about fun than from the composition of tasks. The results showed that Hedonic Value had a significant effect on e-commerce customer satisfaction (Avcilar \& Özsoy, 2015; Hanzaee \& Rezaeyeh, 2013). The higher the value received by customers based on the pleasant experience and pleasure of e-commerce, the more satisfied customers would feel (Chunmei \& Weijun, 2017).

According to Rintamäki et al. (2006), social value plays an important role in determining customer behavior. The effect of social value on customer satisfaction has been investigated in the context of social commerce in China (Chunmei \& Weijun, 2017). Social value is the benefit of a product or service aimed at satisfying one's desires in gaining recognition or social pride (Sheth \& Mittal, 2004). Some studies have confirmed that Social Value has a significant effect on customer satisfaction (Chunmei \& Weijun, 2017; Hu et al., 2014; Kang \& Kim, 2017). This study indicates that the more users can feel the social value the more satisfaction it receives (Chunmei \& Weijun, 2017). 
Furthermore, the Perceived Risk factor as a condition of uncertainty regarding the negative consequences that may arise from using goods and services (Bauer, 1960), is indicated to affect customer satisfaction (Cheng \& Lee, 2011; Martin et al., 2015). The lower the Perceived Risk the customer will further increase customer satisfaction (Chunmei \& Weijun, 2017).

Satisfaction is defined as the user's evaluation of online sales based on their needs and expectations which refers to the positive emotional condition of the user that comes from using the service (Chunmei \& Weijun, 2017). Satisfaction reflects the subjective evaluations of users generated when comparing usage experience with previous expectations about an e-commerce site.

\section{Research methodology}

The research method is quantitative that uses explanatory research to explain the causal relationships between research variables through hypothesis testing (Singarimbun \& Effendi, 1989). The scope of the study examined is the influence of Utilitarian Value, Hedonic Value, Social Value, and Perceived Risk on Customer Satisfaction. The research concept is explained in Figure 1.

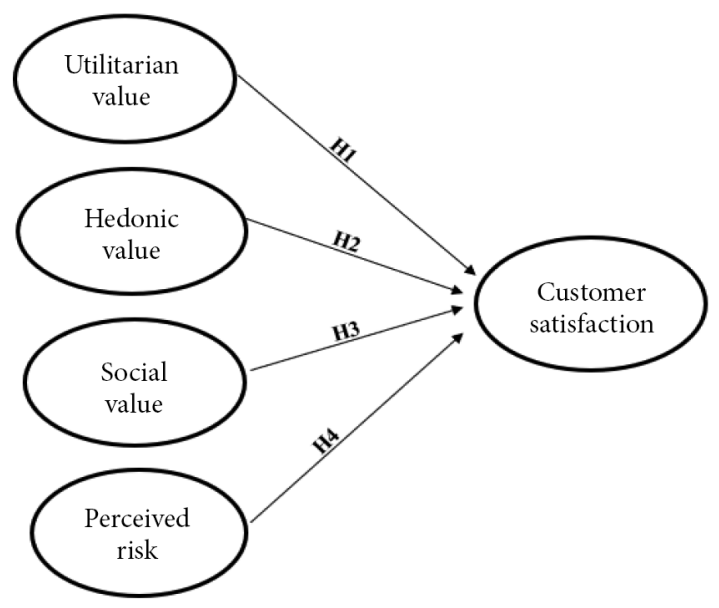

Figure 1. Research model

From the research model above this paper consist of four hypotheses, they are:

H1: Utilitarian value influences customer satisfaction

$\mathrm{H} 2$ : Hedonic value influences customer satisfaction

H3: Social value influences customer satisfaction

H4: Perceived risk influences customer satisfaction

\subsection{Population and sample}

The unit of analysis in this study is the individual. This research is sample research. The population in this study are customers who buy goods and services through ecommerce in Indonesia. The e-commerce chosen includes the top nine e-commerce rankings which are calculated from the number of unique multi-platform comscore.mmx audience versions (2017). The characteristics of the study population are 1) Respondents are customers of e-commerce Lazada.co.id, Blibli.com, Tokopedia. com, Elevenia.co.id, MatahariMall.com, Shopee.co.id, Bukalapak.com, Zalora.co.id, and Blanja.com; who have made shopping purchases at least 2 (two) times in the past 1 month and able to remember the experience of the purchase; 2) Minimum age of respondent is 18 years, 3) Respondents were buyers and users of e-commerce goods and services.

The sampling technique used was purposive sampling by determining the research sample with several considerations aimed at making the data obtained later more representative (Sugiyono, 2015). Indicators that measure variables in this study adopted from previous research: utilitarian value (Chunmei \& Weijun, 2017; Sweeney \& Soutar, 2001; Chiu et al., 2012), hedonic value (Chunmei \& Weijun, 2017; Arnold and Reynolds, 2003), social value (Chunmei \& Weijun, 2017; Rintamäki et al., 2006; Sweeney \& Soutar, 2001; Alshibly, 2017), perceived risk (Boksberger et al., 2007), customer retention (Molinillo et al., 2017).

\subsection{Data collection}

The empirical data were collected via an online survey during the period of January-February in 2020. The instrument used to collect data in research was a questionnaire that was prepared relevant to the data needed by the researchers. Data collection was done by sending online questionnaires using URL addresses to customers who use the internet for product purchase transactions through e-commerce in Indonesia. As the number of users aged 18-67 years old. The questionnaire consisted of several statements using a Likert scale as the measurement scale. A total of 324 responses were collected and scrutinized, 54 were discarded with the same values for all questions or most of the questions. A total of 270 respondents acceptable and feasible to do the analysis.

\subsection{Data analysis}

Partial least squares with WarpPLS 6.0 was employed to validate the measurement model and test the structural model.

\section{Result}

\subsection{Validity and reliability of the instrument}

The calculation results show that the correlation coefficient of all items (statements) is greater than $\geq 0.30$. This means that all statement items are considered valid to be used as instruments for data collection. Reliability tests were carried out on statements already valid using the Cronbach Alpha (Malhotra, 1996). An instrument with a Cronbach Alpha coefficient if $\alpha \geq 0.60$ then said to be reliable. The calculation results showed all items are said to be reliable. 


\subsection{Respondent description}

The frequency distribution in the study is based on the characteristics of the respondents. The results showed that of the 270 respondents, the majority of respondents based on gender were women, namely 144 respondents (52.22\%), while the rest were 129 respondents (47.78\%). Respondents of $53 \%$ or 143 respondents were dominated by respondents in the age range of 18-35 years and the remainder as much as $47 \%$ or 127 respondents were in the age range of 36 years and over. Respondents who received tertiary education were Undergraduate (S1), Graduate 2 (S2) to Postgraduate 3 (S3) as much as $81 \%$ of the total number of respondents in this study, or as many as 220 participating respondents filled out the research questionnaire. Furthermore, the remaining respondents with high school education level/equivalent were 14 respondents (5.19\%), Diploma were 28 respondents (10.37\%), and others were 8 people $(2.96 \%)$.

The income of respondents in this study was $52.96 \%$ of the total respondents or 143 respondents had income ranging from Rp. 2,500,000 to Rp. 7,500,000, then $17.41 \%$ were respondents with income above Rp. 7,500 .000 as many as 47 respondents. Based on the type of work, the majority of respondents were entrepreneurs with 61 respondents (22.59\%), followed by respondents who worked as private employees as many as 51 respondents (18.89\%), teachers/ lecturers as many as 38 respondents (14.07\%), government employees as many as 37 respondents (13.70\%), BUMN employees as many as 26 respondents $(9.63 \%)$, students as many as 14 respondents (5.19\%), students as many as 13 respondents (4.81\%), housewives were 10 respondents (3.70\%), honorary/contract workers were 9 respondents (3.33\%) and social workers were 4 respondents (1.48\%).

Most respondents answered came from the island of Java by $82.96 \%$ which consisted of the provinces of East Java (65.93\%), West Java (5.93\%), Central Java (5.56\%), DI Yogyakarta (2.59\%), DKI Jakarta (2.22\%) and Banten $(0.74 \%)$, while the rest were represented by provinces in other islands in Indonesia. This shows that the most rapid e-commerce development is in Java and the rest outside Java. Furthermore, Tokopedia.com is the most widely used e-commerce by respondents for online purchases, out of 270 respondents as many as 175 respondents have used Tokopedia.com. Furthermore, the second rank of ecommerce that used by respondents was Bukalapak.com, then in a row were Shopee.co.id, Lazada.co.id, Blibli.com, Zalora.co.id, Elevenia.co.id, Blanja.com, and the last was MatahariMall.com.

The results of the study stated that more than $51 \%$ of respondents in the past 1 (one) month, the frequency of shopping using e-commerce was more than 3 times. This shows that the frequency of customers' shopping is quite intense within 1 month. And, respondents considered that the interesting thing on e-commerce sites is the diversity of products offered by 37 respondents (13.40\%). Product prices were also considered by respondents as consumers' attractiveness towards e-commerce as many as
35 respondents (12.96\%). Then in a row, the respondent's answers in evaluating the attractiveness of e-commerce sites were the promotion/discount of 34 respondents (12.59\%), saving time of 32 respondents (11.85\%), free delivery of 31 respondents $(11.48 \%)$, ease of access to sites by 30 respondents $(11.11 \%)$, product quality by 23 respondents $(8.52 \%)$, product guarantees by 21 respondents (7.78\%), ease of transaction by 15 respondents (5.56\%), ease of payment as many as 10 respondents $(3.70 \%)$ and others as many as 2 respondents $(0.74 \%)$.

\subsection{Description of respondent response}

The results of the distribution of respondent's answers to utilitarian value, hedonic value, social value, perceived value, and customer satisfaction are shown in Table 1.

Table 1. Distribution of respondents' answers (sources: primary data that were processed, 2019)

\begin{tabular}{|c|c|c|c|}
\hline Variable & & Indicator item & Mean \\
\hline \multicolumn{3}{|c|}{ Utilitarian Value } & $4.31^{*}$ \\
\hline \multirow[t]{3}{*}{$\begin{array}{l}\text { Product } \\
\text { offerings }\end{array}$} & 1 & $\begin{array}{l}\text { E-commerce sites provide various } \\
\text { product offerings }\end{array}$ & 4.56 \\
\hline & 2 & $\begin{array}{l}\text { E-commerce sites provide product } \\
\text { features that suit the needs of } \\
\text { buyers }\end{array}$ & 4.47 \\
\hline & & & $4.52^{\star *}$ \\
\hline \multirow[t]{3}{*}{$\begin{array}{l}\text { Product } \\
\text { infor- } \\
\text { mation }\end{array}$} & 1 & $\begin{array}{l}\text { E-commerce sites provide detailed } \\
\text { information on the products } \\
\text { displayed }\end{array}$ & 4.20 \\
\hline & 2 & $\begin{array}{l}\text { The e-commerce site provides a } \\
\text { complete list of specifications for } \\
\text { the products displayed }\end{array}$ & 4.16 \\
\hline & & & $4.18^{\star \star}$ \\
\hline \multirow[t]{3}{*}{$\begin{array}{l}\text { Monetary } \\
\text { savings }\end{array}$} & 1 & $\begin{array}{l}\text { This e-commerce site offers the } \\
\text { best product benefits }\end{array}$ & 4.03 \\
\hline & 2 & $\begin{array}{l}\text { Shopping on this e-commerce site } \\
\text { can save you money }\end{array}$ & 4.07 \\
\hline & & & $4.05^{\star *}$ \\
\hline \multirow[t]{3}{*}{$\begin{array}{l}\text { Conven- } \\
\text { ience }\end{array}$} & 1 & $\begin{array}{l}\text { Shopping on this e-commerce site } \\
\text { allows saving time }\end{array}$ & 4.45 \\
\hline & 2 & $\begin{array}{l}\text { This e-commerce site allows } \\
\text { shopping anytime and anywhere }\end{array}$ & 4.57 \\
\hline & & & $4.51^{\star *}$ \\
\hline \multicolumn{3}{|c|}{ Hedonic Value } & $3.80^{*}$ \\
\hline \multirow{3}{*}{$\begin{array}{l}\text { Adven- } \\
\text { ture } \\
\text { Shopping }\end{array}$} & 1 & $\begin{array}{l}\text { Shopping on e-commerce site is a } \\
\text { shopping adventure }\end{array}$ & 4.02 \\
\hline & 2 & $\begin{array}{l}\text { Shopping o e-commerce sites is a } \\
\text { shopping sensation }\end{array}$ & 3.88 \\
\hline & & & $3.95^{* *}$ \\
\hline \multirow[t]{3}{*}{$\begin{array}{l}\text { Social } \\
\text { Shopping }\end{array}$} & 1 & $\begin{array}{l}\text { Shopping with family (friends/ } \\
\text { relatives) to establish brotherhood }\end{array}$ & 3.47 \\
\hline & 2 & $\begin{array}{l}\text { Shopping on e-commerce sites } \\
\text { to socialize with family (friends/ } \\
\text { relatives) }\end{array}$ & 3.36 \\
\hline & & & $3.42^{\star \star}$ \\
\hline
\end{tabular}


Continued Table 1

End of Table 1

\begin{tabular}{|c|c|c|c|c|c|c|c|}
\hline Variable & & Indicator item & Mean & Variable & & Indicator item & Mean \\
\hline \multirow{3}{*}{$\begin{array}{l}\text { Gratifi- } \\
\text { cation } \\
\text { Shopping }\end{array}$} & 1 & $\begin{array}{l}\text { Shopping on e-commerce sites } \\
\text { makes your mood to get better }\end{array}$ & 3.72 & \multirow[t]{3}{*}{$\begin{array}{l}\text { Physical } \\
\text { Risk }\end{array}$} & 1 & $\begin{array}{l}\text { Damage to the product in online } \\
\text { purchases }\end{array}$ & 2.57 \\
\hline & 2 & $\begin{array}{l}\text { Shopping on e-commerce sites to } \\
\text { pamper yourself }\end{array}$ & 3.82 & & \multirow[t]{2}{*}{2} & \multirow[t]{2}{*}{$\begin{array}{l}\text { E-commerce sites do not provide } \\
\text { after-sales guarantees }\end{array}$} & 2.62 \\
\hline & & & $3.77^{\star \star}$ & & & & $2.60^{* *}$ \\
\hline \multirow[t]{3}{*}{\begin{tabular}{|l|} 
Idea \\
Shopping
\end{tabular}} & 1 & $\begin{array}{l}\text { Shopping on e-commerce sites to } \\
\text { see the latest products }\end{array}$ & 4.13 & \multirow{3}{*}{$\begin{array}{l}\text { Psycho- } \\
\text { logical } \\
\text { Risk }\end{array}$} & 1 & $\begin{array}{l}\text { Shopping online provides an } \\
\text { unpleasant experience }\end{array}$ & 2.43 \\
\hline & \multirow[t]{2}{*}{2} & \multirow[t]{2}{*}{$\begin{array}{l}\text { Shopping on e-commerce sites to } \\
\text { keep up with trends }\end{array}$} & 3.63 & & \multirow[t]{2}{*}{2} & \multirow[t]{2}{*}{$\begin{array}{l}\text { Shopping online gives concern to } \\
\text { the condition of the product }\end{array}$} & 2.76 \\
\hline & & & $3.88^{* \star}$ & & & & $2.60^{* *}$ \\
\hline \multirow[t]{3}{*}{$\begin{array}{l}\text { Role } \\
\text { Shopping }\end{array}$} & 1 & $\begin{array}{l}\text { Shopping in e-commerce site for a } \\
\text { special person }\end{array}$ & 3.57 & \multirow[t]{3}{*}{$\begin{array}{l}\text { Social } \\
\text { Risk }\end{array}$} & 1 & $\begin{array}{l}\text { Shopping online does not give the } \\
\text { impression of prestige }\end{array}$ & 2.58 \\
\hline & \multirow[t]{2}{*}{2} & \multirow[t]{2}{*}{$\begin{array}{l}\text { Shopping on e-commerce sites so } \\
\text { that other people feel happy }\end{array}$} & 3.37 & & \multirow[t]{2}{*}{2} & \multirow[t]{2}{*}{$\begin{array}{l}\text { Shopping online does not provide } \\
\text { a good reputation }\end{array}$} & 2.45 \\
\hline & & & $3.47^{\star *}$ & & & & $2.52^{\star *}$ \\
\hline \multirow{4}{*}{$\begin{array}{l}\text { Value } \\
\text { Shopping }\end{array}$} & \multirow{2}{*}{1} & \multirow{2}{*}{$\begin{array}{l}\text { Shopping on e-commerce sites to } \\
\text { hunt for cheap stuff }\end{array}$} & \multirow{2}{*}{4.30} & \multirow{4}{*}{$\begin{array}{l}\text { Temporal } \\
\text { Risk }\end{array}$} & 1 & Shopping online is troublesome & 2.17 \\
\hline & & & & & \multirow{3}{*}{2} & \multirow{3}{*}{$\begin{array}{l}\text { Shopping online gives a concern } \\
\text { that there will be a delay in } \\
\text { shipping the product }\end{array}$} & \\
\hline & \multirow[t]{2}{*}{2} & $\begin{array}{l}\text { Shopping on e-commerce sites to } \\
\text { get discounts }\end{array}$ & 4.33 & & & & 2.73 \\
\hline & & & $4.32^{\star *}$ & & & & $2.45^{* *}$ \\
\hline \multicolumn{3}{|c|}{ Social Value } & $3.56^{\star}$ & \multicolumn{3}{|c|}{ Customer Satisfaction } & $3.98^{\star}$ \\
\hline \multirow{3}{*}{$\begin{array}{l}\text { Feel } \\
\text { accep- } \\
\text { table }\end{array}$} & 1 & $\begin{array}{l}\text { Shopping on e-commerce sites } \\
\text { helps to feel accepted by others }\end{array}$ & 3.37 & \multirow{4}{*}{$\begin{array}{l}\text { Purchase } \\
\text { Expe- } \\
\text { rience }\end{array}$} & 1 & $\begin{array}{l}\text { Satisfied with the purchasing } \\
\text { experience }\end{array}$ & 4.17 \\
\hline & 2 & $\begin{array}{l}\text { Share shopping experiences with } \\
\text { others }\end{array}$ & 3.91 & & 2 & $\begin{array}{l}\text { Satisfied with experience before } \\
\text { purchase }\end{array}$ & 3.86 \\
\hline & & & $3.64^{* *}$ & & \multirow[b]{2}{*}{3} & \multirow{2}{*}{$\begin{array}{l}\text { Satisfied with the post-purchase } \\
\text { experience }\end{array}$} & 4.01 \\
\hline \multirow{3}{*}{$\begin{array}{l}\text { Good } \\
\text { impres- } \\
\text { sion }\end{array}$} & 1 & $\begin{array}{l}\text { Shopping on e-commerce sites } \\
\text { gives a good impression on others }\end{array}$ & 3.58 & & & & \\
\hline & & I feel part of this e-commerce site & 3.56 & Choice of & & The cho & \\
\hline & 2 & & $3.57^{\star *}$ & Sites & 1 & e-commerce site for shopping is a & 3.91 \\
\hline $\begin{array}{l}\text { I am } \\
\text { perceived }\end{array}$ & 1 & Shopping on e-commerce sites & 3.39 & & & & \\
\hline ceived & 0 & E-commerce sites offer consistent & 3.85 & & 2 & $\begin{array}{l}\text { e-commerce sites in shopping is } \\
\text { satisfying }\end{array}$ & 3.95 \\
\hline & 2 & & $3.62^{\star *}$ & & 3 & $\begin{array}{l}\text { The right decision to use an } \\
\text { e-commerce site to shop }\end{array}$ & 3.96 \\
\hline $\begin{array}{l}\text { Social } \\
\text { approval }\end{array}$ & 1 & $\begin{array}{l}\text { Shopping on e-commerce sites } \\
\text { makes it easy to be accepted in }\end{array}$ & 3.38 & & $J$ & & $3.94^{* *}$ \\
\hline
\end{tabular}

Note: Mean variable ${ }^{\star}$, Mean indicator ${ }^{\star *}$.

The results showed the average score of the respondents' answers to the Utilitarian Value variable was 4.31 or very high. This indicates the Utilitarian Value of respondents tends to be very positive or very good. Very high respondents perceive functional benefits and tradeoffs from using products and services.

The findings showed that the average score of the distribution of respondents' answers to the Hedonic Value variable was 3.80 or high. This indicates that the Hedonic Value of respondents tends to be positive or good. High respondents perceive the high value of the customer received based on pleasant experiences and pleasures.

The findings showed the average score of the distribution of respondents' answers on the Social Value variable of 3.56 or high. This indicates the respondent's Social Value tends to be positive or good. Respondents highly 
perceive the benefits of products or services aimed at satisfying one's desires in gaining recognition or social pride.

Other findings also showed that the average score of the distribution of respondents' answers to the Perceived Risk variable was 2.50 or moderate. This indicates that respondents' Perceived Risk tends to be middle or moderate. Respondents are perceiving conditions of uncertainty regarding the negative consequences that may arise from using goods and services.

Finally, the results showed the average score of the distribution of respondents' answers to the Customer Satisfaction variable was 3.98 or high. This indicates the respondent's Customer Satisfaction tends to be positive or high. Respondents are high in perceiving the subjective evaluations of users generated when comparing usage experiences with previous expectations about an e-commerce site.

\subsection{Result of reliability and validity construct}

Ideally the AVE value is shown by looking at the factor loading value $\geq 0.50$ then said to be valid. The results of a construct are said to have good convergent validity of the loading factor value $\geq 0.50$. According to Solimun et al. (2017), composite Reliability and Cronbach's Alpha values are used to know the reliability of research instruments. Composite reliability is fulfilled or reliable if it is of value $>0.70$ so the questionnaire for all variables is to fulfill the composite reliability. Another criterion used is looking at the Cronbach's Alpha coefficient, said to be reliable if it has an Alpha value $>0.60$. The results of the validity and reliability construct are shown in Table 2 .

Table 2. Results of validity and reliability construct (sources: primary data that were processed, 2018)

\begin{tabular}{|c|c|c|c|}
\hline \multicolumn{1}{|c|}{ Variable } & $\begin{array}{c}\text { Cronbach } \\
\text { Alpha }\end{array}$ & $\begin{array}{c}\text { Composites } \\
\text { Reliability }\end{array}$ & AVE \\
\hline Utilitarian Value & $0.764^{* * *}$ & $0.849^{* *}$ & $0.765^{\star}$ \\
\hline Product offerings & & & 0.756 \\
\hline Product information & & & 0.774 \\
\hline Monetary savings & & & 0.761 \\
\hline Convenience & & & 0.769 \\
\hline Hedonic Value & $0.762^{\star * *}$ & $0.837^{* *}$ & $0.688^{\star}$ \\
\hline Adventure Shopping & & & 0.652 \\
\hline Social Shopping & & & 0.695 \\
\hline Gratification & & & 0.806 \\
\hline Shopping & & & 0.747 \\
\hline Idea Shopping & & & 0.784 \\
\hline Role Shopping & & & 0.336 \\
\hline Value Shopping & & & $0.837^{\star}$ \\
\hline Social Value & $0.903^{* * *}$ & $0.856^{\star *}$ & 0.837 \\
\hline Feel acceptable & & & 0.874 \\
\hline Good impression & & & 0.845 \\
\hline I am perceived & & & 0.788 \\
\hline Social approval) & & & \\
\hline
\end{tabular}

End of Table 2

\begin{tabular}{|c|c|c|c|}
\hline Variable & $\begin{array}{c}\text { Cronbach } \\
\text { Alpha }\end{array}$ & $\begin{array}{c}\text { Composites } \\
\text { Reliability }\end{array}$ & AVE \\
\hline Perceived Risk & $0.920^{\star * \star}$ & $0.896^{\star *}$ & $0.811^{\star}$ \\
\hline Financial Risk & & & 0.773 \\
\hline Functional Risk & & & 0.805 \\
\hline Physical Risk & & & 0.835 \\
\hline Psychological Risk & & & 0.842 \\
\hline Social Risk & & & 0.816 \\
\hline Temporal Risk & & & 0.794 \\
\hline Customer Satisfaction & $0.841^{\star * *}$ & $0.927^{\star *}$ & $0.929^{\star}$ \\
\hline $\begin{array}{l}\text { Purchasing } \\
\text { Experience }\end{array}$ & & & 0.929 \\
\hline Site Selection & & & 0.929 \\
\hline
\end{tabular}

Note: AVE $\geq 0.50^{\star}$, Composite reliability $\geq 0.70^{\star \star}$, Cronbach alpha $\geq 0.60^{\star * *}$.

The results in Table 2, can be seen that the overall AVE value of the five variables has an AVE value greater than ${ }^{3} 0.50$ thus it can be stated as ideal. Utilitarian value has a value of AVE 0.765, hedonic value has a value of AVE 0.688 , social value has a value of AVE 0.837 , perceived value has a value of AVE 0.811 , and customer satisfaction has a value of AVE 0.929 .

The findings for the overall Composite reliability value on five variables are greater than 0.70 so they can be declared reliable. Utilitarian value has Composite reliability value 0.849 , hedonic value has Composite reliability value 0.837, social value has Composite reliability value 0.856 , perceived value has Composite reliability value 0.896 , and customer satisfaction has Composite reliability value 0.927 .

The last finding in Table 2 shows the overall Cronbach's alpha value on five variables whose value is greater than 0.60 thus it can be declared reliable. Utilitarian value has Cronbach's alpha value 0.764 , hedonic value has Cronbach's alpha value 0.762 , social value has Cronbach's alpha value 0.903 , perceived value has Cronbach's alpha value 0.920 , and customer satisfaction has Cronbach's alpha value 0.841 .

\subsection{Hypotheses tests}

Figure 2 presents the results of the path coefficients and the corresponding levels of significance. In this study we have tested 4 kinds of asymmetric relationships between variables. The causal relationship criterion is hypothesized using a significant p-value limit $£ 5 \%(0.05)$ stated as significant. Utilitarian value, hedonic value, social value and perceived risk have significant and positive influences on customer satisfaction, hence $\mathrm{H} 1, \mathrm{H} 2$, and $\mathrm{H} 3$ are confirmed. The perceived risk significantly and negatively influences on customer satisfaction, thereby verifying $\mathrm{H} 4$. 


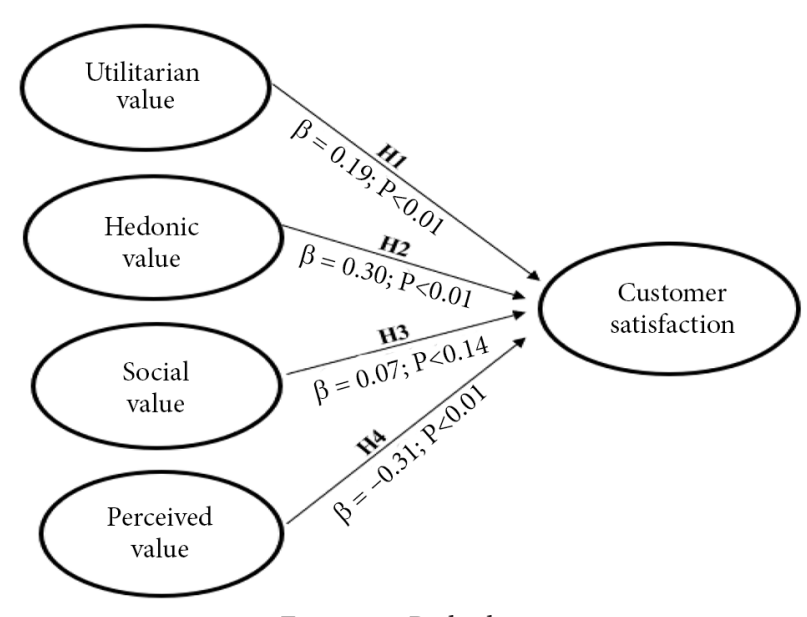

Figure 2. Path chart

\section{Discussion}

This study aims to explore the influence of utilitarian value, hedonic value, social value, and perceived risk on customer satisfaction: a survey of e-commerce customers in Indonesia.

\section{H1: Utilitarian Value has a significant effect on Customer Satisfaction}

The results of the analysis obtained the value of the influence of Utilitarian Value on Customer Satisfaction with a path coefficient of 0.192 and $p<0.001$. The path coefficient is positive (0.192) and a p-value less than 0.05 is said to be significant, so the hypothesis is accepted. The higher Utilitarian Value can increase Customer Satisfaction. The findings of this study are the Utilitarian Value significantly and positively influence Customer Satisfaction.

The research findings produced are good Utilitarian Value in the minds of consumers is one of the important factors that drive the satisfaction of e-commerce customers. Utilitarian Value is a key factor in the analysis of consumer behavior before purchasing goods and services on e-commerce sites. The customer depends on his knowledge of e-commerce products in evaluating whether these products can meet customer needs. Knowledge of the benefits of the product is also a fundamental requirement for customers in buying goods and services on e-commerce sites (Chunmei \& Weijun, 2017; Sweeney \& Soutar, 2001). This knowledge help fulfill the needs and satisfaction of ecommerce customers. This finding provides sufficient reason to conclude that customers who get a thorough assessment of functional benefits and sacrifices about products on e-commerce sites will be satisfied. A positive Utilitarian Value will result in satisfaction which means a positive perception of Utilitarian Value is important for increasing e-commerce customer satisfaction.

This study shows that Utilitarian Value is a direct determinant of satisfaction meaning that a positive perception of Utilitarian Value is important to increase satisfaction. E-commerce marketers must continue to strive to make positive Utilitarian Value and ensure customers to be very satisfied. E-commerce marketers must pay attention to the important role of Utilitarian Value in stimulating e-commerce customer satisfaction. The implications of this research first, e-commerce marketer must find the right approach in creating a positive Utilitarian Value of ecommerce sites. The challenge can be in the form of attractive product offerings accompanied by product features according to customer needs. Second, detailed information along with e-commerce product specifications must be displayed in full on the e-commerce site. E-commerce sites offer the best benefits from e-commerce products and services. Third, the most important e-commerce site can provide saving money and time, and can be accessed anytime and anywhere thus all online shopping needs can be met based on functional benefits. Fourth, E-commerce marketers provide a variety of products and services. The more variety contained, it will attract consumers to visit and shop on e-commerce sites.

\section{H2: Hedonic Value has a significant effect on customer satisfaction}

The results of the analysis obtained value of the influence of Hedonic Value on Customer Satisfaction with a path coefficient of 0.300 and $p<0.001$. The path coefficient is positive (0.300) and a p-value less than 0.05 is said to be significant, so the hypothesis is accepted. The higher Hedonic Value can increase Customer Satisfaction. The findings of this study are the Hedonic Value significantly and positively influence Customer Satisfaction.

The findings of this study support the opinion that customers who shop are influenced by the presence of hedonic shopping values, namely pleasure and excitement when shopping (Jones \& Sasser, 1995). Hedonic is more subjective and personal because it is related to the desire for pleasure and self-expression related to the emotional needs of individuals for shopping experiences. This supports the concept put forward that pleasure is a hedonic element when customers shop online (Wolfinbarger \& Gilly, 2001). If the customer in purchasing e-commerce products provides a pleasant experience, it will increase customer satisfaction. The higher the Hedonic Value, the higher the customer satisfaction. The results showed similarities with the results of previous studies (Chunmei \& Weijun, 2017; Avcilar \& Özsoy, 2015).

Based on the results of the highest loading factor, the Gratification Shopping indicator is 0.806 . The purpose of gratification shopping is shopping done to relieve stress, shop to reduce negative moods, and shopping as a special gift for yourself. Customers after shopping on e-commerce sites make a better mood, then customers feel satisfied after shopping. These experiences provide a feeling of comfort and pleasure that creates a positive Hedonic Value. A positive hedonic value can produce satisfaction meaning a positive perception of hedonic value is important for increasing e-commerce customer satisfaction. 
The implications of this research first, e-commerce marketers must find the right approach to develop marketing strategies by creating a positive Hedonic Value of e-commerce sites. This approach is intended for satisfaction such as relieving stress, shopping to reduce negative moods, and shopping as a special gift for yourself. The challenge for Marketers is that e-commerce sites can display products that are entertaining and interactive that make the mood better. Second, hedonic customers can be spoiled with e-commerce sites with the theme of events and contests, game zones, music, discussion rooms, and the overall store atmosphere that makes the shopping experience more entertaining and exploring. E-commerce sites with the above themes can spoil customers to give a feeling of pleasure and excitement when shopping online.

\section{H3: Social Value has no significant effect on customer satisfaction}

The results of the analysis obtained the value of the influence of Social Value on Customer Satisfaction with a path coefficient of 0.065 and $p<0.140$. The path coefficient is positive $(0.065)$ and a p-value greater than 0.05 is said to be insignificant, so the hypothesis is rejected. This means that the higher Social Value can increase Customer Satisfaction, even though the increase is not significant. The findings of this study are that Social Value does not have a significant effect on the positive direction of Customer Satisfaction. This means that even though e-commerce site customers have a positive Social Value of e-commerce sites, it does not guarantee customer satisfaction in the future.

Empirical data in this study does not provide proof of the concept of Social Value. Consumers make purchasing decisions by considering Social Value will choose products or services that communicate an image that is in harmony with norms or that can convey the social image that they want to display. This study shows that Social Value has no significant effect on customer satisfaction. The findings of this study support the results of previous studies that Social Value does not affect customer satisfaction (Prebensen \& Rosengren, 2016).

A review of the literature and profile of respondents explains why Social Value does not have a significant effect on satisfaction. First, the characteristics of respondents based on the source of information on the existence of e-commerce mostly obtained through social media as many as 112 respondents (41.48\%), followed by print media 95 respondents $(35.19 \%)$ and print media 25 respondents (9.26\%). Respondents with such backgrounds are customers who lack social interaction with others. Social interaction plays an important role in building Social Value that reflects the need for bonding and socializing. Different results if the characteristics of respondents are based on the reference to the existence of e-commerce which is dominated by friends and family, the results indicate a high social interaction. This is not used as a basis for evaluating satisfaction, so Social Value does not have a significant effect on satisfaction. Second, respondents' answers to items on the Social Value variable mostly answered neutrally on the mean indicator of the Social Value variable. The biggest dominance in neutral answers to the respondents' contributions shows that customers can do shopping individually therefore sometimes the need for Social Value is not too important.

\section{H4: Testing the influence of perceived risk has a significant effect on customer satisfaction}

The results of the analysis obtained the value of the effect of Perceived Risk on Customer Satisfaction with a path coefficient of -0.310 and $p<0.001$. The path coefficient is negative $(-0.310)$ and a p-value less than 0.05 is said to be significant, so the hypothesis is accepted. The lower Perceived Risk can increase Customer Satisfaction. The findings of this study are that Perceived Risk has a significant and negative effect on Customer Satisfaction. Perceived risks play an important role in shaping or inhibiting user satisfaction and purchase intentions (Hunter et al., 2004). When users feel the risk when using e-commerce sites, they may feel dissatisfied with the site and are hesitant to buy through the site. The more the customer feels a low risk, the more satisfaction they will feel and they will purchase (Pires et al., 2004). This finding supports previous research (Chunmei \& Weijun, 2017).

Literature review and description analysis of respondents explain why Perceived Risk has a significant effect on Customer Satisfaction. First, the characteristics of respondents based on age dominated by customers aged $36-45$ years (39 people/34.44\%) are classified as age who are accustomed to using internet technology or literate technology enable. Customers with this background have experience using the internet for online purchases and comparing one e-commerce site with other e-commerce sites. This experience helps customers to reduce risks in online purchases using e-commerce sites. Therefore, this finding supports that the lower Perceived Risk will increase e-commerce customer satisfaction.

Second, the level of education affects the online purchasing decision process of respondents both in their way of thinking, perspective, and even perception in dealing with problems in a decision. Respondents with a good level of education tend to be more responsive to information. The level of intellectuality influences respondents in determining the choice of goods and services, product brands, uses, benefits, risks, and so on. Most respondents were respondents with a bachelor degree (S2) of 122 respondents $(45.19 \%)$, considered to be respondents with intellectual property, tendency to consider the perceived risk to the satisfaction of purchasing e-commerce products

Third, based on e-commerce shopping frequency, it shows that most respondents were respondents with a shopping frequency of 4 times in the last 1 (one) month, with the number of respondents as many as 107 respondents (39.63\%). This frequency is enough to provide information and experience for respondents about online 
purchases using e-commerce sites. The more frequency of purchases that have been made the more information that can be used in providing online purchase references using e-commerce sites.

The implications of this study are first, e-commerce marketers need to understand the risks perceived in online purchases using e-commerce sites. These risks can reduce and increase customer satisfaction. The lower the perceived risk will increase consumer satisfaction in purchasing e-commerce products. The marketing strategies developed by e-commerce marketers must lead to a reduction in Perceived Risk in online purchases. Second, e-commerce marketers need to inform things that can help respondents to reduce the risk of their purchases such as information on terms and conditions of purchase (terms and conditions), product ratings and reviews, Seller Recommendations (product ratings), etc.

\section{Conclusions and future research}

\section{Conclusions}

The purpose of this study is to build an understanding of the influence of utilitarian values, hedonic values, social values, and perceived risk on e-commerce customer satisfaction in Indonesia. The results of the study show that Utilitarian Value significantly influences Customer Satisfaction, meaning that the level of Utilitarian Value of e-commerce customers will affect the level of Customer Satisfaction. In other words, the better (higher) Utilitarian Value given by e-commerce products will lead to satisfaction with e-commerce customers. Hedonic Value significantly influences Customer Satisfaction, meaning that the high and low Hedonic Value of e-commerce customers will affect the level of Customer Satisfaction. In other words, the higher the Hedonic Value given by e-commerce products will lead to the satisfaction of e-commerce customers. Social Value does not have a significant effect on Customer Satisfaction, meaning that the level of the social value of e-commerce customers does not have a significant impact on the level of customer satisfaction. Perceived Risk significantly influences Customer Satisfaction, meaning that the level of Perceived Risk of e-commerce customers will affect the level of Customer Satisfaction. In other words, the lower Perceived Risk given by e-commerce products will lead to satisfaction with e-commerce customers.

\section{Limitation and directions for future research}

This study has several limitations. (1) This research is explanatory research conducted in a short time, thus the findings in this study cannot describe the movement of an object over a long period, (2) This study only focuses on nine e-commerce sites in Indonesia; thus, this research cannot be generalized to all e-commerce in Indonesia. (3) The number of respondents in this study was 270 respondents, the next research could involve more and more respondents to provide more relevant results.
Future studies are suggested (1) to examine the same research model as research objects with e-commerce characteristics from different business scales and segmentation, thus empirically consistent findings from the theories used in this study can be tested. (2) Subsequent research uses the characteristics of different customers (individuals and families) to analyze customer behavior with the sample used to remain the same, e-commerce customers. (3) This study only uses e-commerce as the online retail industry as an object of observation, for other studies it is recommended to develop observations with more diverse industries and even compare between different industries.

\section{References}

Alshibly, H. H. (2017). Customer perceived value in social commerce: an exploration of its antecedents and consequences. Journal of Management Research, 7(7), 17-37. https://doi.org/10.5296/jmr.v7i1.6800

Arnold, M. J., \& Reynolds, K. (2003). Hedonic shopping motivations. Journal of Reiling, 79(2), 77-95. https://doi.org/10.1016/S0022-4359(03)00007-1

Avcilar, M. Y., \& Özsoy, T. (2015). Determining the effects of perceived utilitarian and Utilitarian Value on Online shopping intentions. International Journal of Marketing Studies, 7(6), 27-49. https://doi.org/10.5539/ijms.v7n6p27

Bauer, R. A. (1960). Consumer behavior as risk taking. In R. S. Hancock (Ed.), Dynamic marketing for a Changing World: Proceedings of the 43rd National Conference of the American Marketing Association (pp. 389-398). Chicago American Marketing Association.

Boksberger, P. E., Bieger, T., \& Laesser, C. (2007). Multidimensional analysis of Perceived Risk in commercial air travel. Journal of Air Transport Management, 13(2), 90-96. https://doi.org/10.1016/j.jairtraman.2006.10.003

Cheng, C., \& Lee, A. (2011). The influences of relationship marketing strategy and transaction cost on customer satisfaction, perceived risk, and customer loyalty. African Journal of Business Management, 5(13), 5199-5209. https://doi.org/10.1111/j.1365-2575.2012.00407.x

Chiu, C.-M., Wang, E. T. G., Fang, Y.-H., \& Huang, H.-Y. (2012). Understanding customers' repeat purchase intentions in $\mathrm{B} 2 \mathrm{C}$ e-commerce: the roles of utilitarian value, utilitarian value, and perceived risk. Information Systems Journal, 24(1), 85114. https://doi.org/10.1111/j.1365-2575.2012.00407.x

Chunmei, G., \& Weijun, W. (2017). The influence of perceived value on purchase intention in social commerce context. Internet Research, 27(4), 772-785.

https://doi.org/10.1108/IntR-06-2016-0164

Constantin, A. M. (2013). The antecedents of e-satisfaction and e-loyalty. Timisoara Journal of Economics, 5(2), 236-252.

Hanzaee, K. H., \& Rezaeyeh, S. P. (2013). Investigation of the effects of utilitarian value and utilitarian value on customer satisfaction and behavioural intentions. African Journal of Business Management, 7(11), 818-825.

$\mathrm{Hu}, \mathrm{T}$., Kettinger, W. J., \& Poston, R. S. (2014). The effect of online Social Value on satisfaction and continued use of social media. European Journal of Information Systems, 24(4), 391410. https://doi.org/10.1057/ejis.2014.22

Hunter, L. M., Kasouf, C. J., Celuch, K. G., \& Curry, K. A. (2004). A classification of business-to-business buying decisions: risk importance and probability as a framework for e-business 
benefits. Industrial Marketing Management, 33(2), 145-154. https://doi.org/10.1016/S0019-8501(03)00058-0

Jones, T. O., \& Sasser, W. E. (1995). Why satisfied customers defect. Harvard Business Review, (November/December), 88-99.

Kang, H. Y, \& Kim, J. (2017). Customer's social value perception and enterprise's sustainability: focus on social enterprise. $J_{o-}$ urnal of Marketing Thought, 4(2), 71-77.

Kesari, B., \& Atulkar, S. (2016). Satisfaction of mall shoppers: a study on perceived utilitarian and hedonic shopping values. Journal of Retailing and Consumer Services, 31, 22-31. https://doi.org/10.1016/j.jretconser.2016.03.005

Malhotra, N. K. (1996). Marketing research. An applied orientation (2nd ed.). Salemba Empat. Jakarta.

Martin, J., Mortimer, G., \& Andrews, L. (2015). Re-examining online customer experience to include purchase frequency and Perceived Risk. Journal of Retailing and Consumer Services, 25(2015), 81-95. https://doi.org/10.1016/j.jretconser.2015.03.008

Molinillo, S., Gómez-Ortiz, B., Pérez-Aranda, J., \& Navarro-García, A. (2017). Building customer loyalty: the effect of experiential state, the value of shopping, and trust and perceived value of service on online clothes shopping. Clothing and Textiles Research Journal, 35(3), 156-171. https://doi.org/10.1177/0887302X17694270

Pires, G., Stanton, J., \& Eckford, A. (2004). Influences on the perceived risk of purchasing online. Journal of Consumer Behaviour, 4(2), 118-131. https://doi.org/10.1002/cb.163

Prebensen, N. K., \& Rosengren, S. (2016). Experience value as a function of hedonic and utilitarian dominant services. International Journal of Contemporary Hospitality Management, 28(1). https://doi.org/10.1108/IJCHM-02-2014-0073
Rintamäki, T., Kanto, A., Kuusela, H., \& Spence, M. T. (2006). Decomposing the value of department store shopping into utilitarian, hedonic and social dimensions. International Journal of Retail and Distribution Management, 34(1), 6-24. https://doi.org/10.1108/09590550610642792

Sheth, J. N., \& Mittal, B. (2004). Consumer behavior: a managerial perspective (2nd ed.). South-Western, USA.

Singarimbun, M., \& Sofian, E. (1989). Metode Penelitian Survai. LP3ES. Jakarta.

Solimun, Fernandes, A. A. R., \& Nurjannah. (2017). Metode Statistika Multivariate: Permodelan Struktural (SEM) Pendekatan WarpPLS. UB Press.

Sugiyono. (2015). Metode Penelitian Untuk Manajemen. Penerbit Alfabeta. Yogyakarta.

Sweeney, J. C., \& Soutar, G. N. (2001). Consumer perceived value: the development of a multiple-item scale. Journal of Retailing, 77(2), 203-220. https://doi.org/10.1016/S0022-4359(01)00041-0

Wolfinbarger, M., \& Gilly, M. (2001). Shopping online for freedom, control, and fun. California Management Review, 43(2), 34-55. https://doi.org/10.2307/41166074

Wood, C. M., \& Scheer, L. K. (1996). Incorporating perceived risk into models of consumer deal assessment and purchase intent. Advances in Consumer Research, 23(1), 399-404.

Zeithaml, V. A. (1988). Consumer perceptions of price, quality, and value: a means-end model and synthesis of evidence. Journal of Marketing, 52(3), 2-22. https://doi.org/10.1177/002224298805200302 